\title{
PM2.5 induces apoptosis, oxidative stress injury and melanin metabolic disorder in human melanocytes
}

\author{
DANFENG SUO ${ }^{1}$, SANWU ZENG $^{1}$, JUNLING ZHANG $^{2}$, LINGHE MENG $^{1}$ and LISHUO WENG ${ }^{1}$ \\ ${ }^{1}$ Department of Dermatology, Tianjin First Center Hospital, Tianjin 300192; ${ }^{2}$ Department of Dermatology, \\ Tianjin Academy of Traditional Chinese Medicine Affiliated Hospital, Tianjin 300120, P.R. China
}

Received July 25, 2018; Accepted December 19, 2019

DOI: $10.3892 /$ etm.2020.8590

\begin{abstract}
Recent growing evidence suggested that particulate matter 2.5 (PM2.5) has strong toxic effects on skin systems. However, the possible effects and the mechanisms of PM2.5 on vitiligo remain poorly understood. Therefore, the present study aimed to further investigate the effects and possible mechanisms of PM2.5 on vitiligo. Human keratinocytes (HaCaT cells) and human melanocytes (PIG1 cells and PIG3V cells) were exposed to PM2.5 $(0-200 \mu \mathrm{g} / \mathrm{ml})$ for $24 \mathrm{~h}$. The cell viability of the three cell lines was measured by a Cell Counting Kit- 8 assay. The secretions of stem cell factor (SCF) and basic fibroblast growth factor (bFGF) in HaCaT cells were evaluated by ELISA. The melanin contents, cellular tyrosinase activity, apoptosis, cell migration, malondialdehyde (MDA) contents, superoxide dismutase (SOD) levels, glutathione peroxidase (GSH-Px) levels and related protein expressions in PIG1 cells and PIG3V cells were evaluated by a $\mathrm{NaOH}$ assay, DOPA assay, Annexin V-FITC/Propidium Iodide staining, MDA assay, SOD assay, GSH-Px assay and western blotting, respectively. It was demonstrated that PM2.5 exposure inhibited cell viability of all three cell lines (HaCaT, PIG1 and PIG3V cells). PM2.5 exposure attenuated the secretions of SCF and bFGF in HaCaT cells. Moreover, PM2.5 exposure attenuated the activation of tyrosinase and melanogenesis, inhibited cell migration, and induced apoptosis and oxidative stress injury in PIG1 cells and PIG3V cells. In addition, PM2.5 exposure caused upregulated cytosolic cytochrome $\mathrm{C}$ and activated caspase-3 in PIG1 cells and PIG3V cells. Furthermore, PM2.5 exposure activated the nuclear factor erythroid 2-related factor 2 and heme oxygenase-1 signaling pathway. The present results suggested that PM2.5 exposure could inhibit the secretions of SCF and bFGF in keratinocytes, and cause oxidative stress injury and melanin metabolic disorder in melanocytes. Therefore, PM2.5 could be a new risk factor for vitiligo.
\end{abstract}

Correspondence to: Dr Sanwu Zeng, Department of Dermatology, Tianjin First Center Hospital, 24 Fukang Road, Nankai, Tianjin 300192, P.R. China

E-mail: sanwuzeng@126.com

Key words: particulate matter 2.5 , vitiligo, melanin metabolic disorder, oxidative stress injury, apoptosis, human melanocytes

\section{Introduction}

Vitiligo is a common skin disease which is the most frequent cause of depigmentation, resulting in prominent and disfiguring white spots. At present, to the best of the authors' knowledge, there are no specific drugs for treatment of this kind of skin disorder (1,2). Vitiligo pathogenesis often involves dysfunction or absence of melanocytes. A number of previous studies showed that oxidative stress injury of melanocytes plays an important role in vitiligo (1-3).

Particulate matter 2.5 (PM2.5) refers to particles in the atmosphere with an aerodynamic diameter $<2.5 \mu \mathrm{m}$ (4). It is well known to contribute to air pollution and is closely associated with human health problems $(4,5)$. Previous epidemiological studies have demonstrated that PM2.5 was associated with the increasing prevalence and mortality rates of respiratory and cardiovascular diseases (6-10). In addition, a previous study identified that PM2.5 was a crucial risk factor for skin diseases and skin aging (11). The cytotoxicity of PM2.5 on human keratinocytes (HaCaT cells), which is related to the inflammatory response, could be a cause of PM2.5-induced skin injury (12). The main pathways of the PM2.5 toxic effect are related to oxidative stress injury, the inflammatory response, skin barrier function impairment and genetic damage (13-15). In a previous study, human lung epithelial cells (BEAS-2B) exposed to PM2.5 caused a high expression of heme oxygenase-1 (HO-1) and autophagy-related cell necrosis (16). While, hydrogen peroxide could induce oxidative stress in human melanocytes via nuclear factor erythroid 2-related factor 2 (Nrf2)-driven transcriptional activation of $\mathrm{HO}-1$, and it could be a possible mechanism for melanocyte degeneration in vitiligo $(17,18)$. However, more research into the mechanisms linking PM2.5 and skin damage is still required. Considering the epidermal oxidative stress in patients with vitiligo, the present study aimed to identify the possible association between PM2.5 and vitiligo, which could provide insight on the underlying mechanisms of vitiligo.

Based on previous investigations on the functions of PM2.5, the present study aimed to investigate the effects of PM2.5 exposure on human keratinocytes (immortalized human keratinocyte $\mathrm{HaCaT}$ cells) and human melanocytes (immortalized human epidermal melanocyte PIG1 cells and immortalized vitiligo melanocyte PIG3V cells) in vitro. Specifically, the effects of PM2.5 exposure on cell viability and the secretions 
of stem cell factor (SCF) and basic fibroblast growth factor (bFGF) in $\mathrm{HaCaT}$ cells, and cell migration, apoptosis and oxidative stress injury in PIG1 cells and PIG3V cells were investigated. The findings of the present study suggested that PM2.5 exposure could inhibit the secretions of SCF and bFGF in keratinocytes, and cause oxidative stress injury and melanin metabolic disorder in melanocytes. Thus, PM2.5 could be a new risk factor for vitiligo.

\section{Materials and methods}

Collection of PM2.5. PM2.5 was obtained from the mouth of the Yangtze River at China's central eastern coast in Shanghai using a QJS-100 multi-level flow particulate matter cutter (Jinzhou Licheng Technology Development Co., Ltd.). The cutter was placed on the roadside for $48 \mathrm{~h}$ at a constant aspiration flow rate $(100 \mathrm{l} / \mathrm{min})$. Then, the PM2.5 fiber filters were transferred to ultrapure water and subjected to ultrasonic oscillations for $15 \mathrm{~min}$ in order to elude the particulate matter. The sample was vacuum freeze-dried for $24 \mathrm{~h}$ and then, the sample was collected in a $50 \mathrm{ml}$ centrifuge tube and diluted with PBS. The PM2.5 suspension was autoclaved at $120^{\circ} \mathrm{C}$ for 30 min. Finally, the PM2.5 suspension was collected and stored at $4^{\circ} \mathrm{C}$. According to the literature (19), the main compositions of PM2.5 were analyzed by gas-mass spectrometry and X-ray fluorescence spectroscopy.

Cell culture and treatment. The human keratinocyte $\mathrm{HaCaT}$ cells (American Type Culture Collection; ATCC) were cultured in DMEM (containing $1.05 \mathrm{mM}$ calcium chloride; Gibco; Thermo Fisher Scientific, Inc.) supplemented with $10 \%$ FBS (Gibco; Thermo Fisher Scientific, Inc.) in a humidified atmosphere of $5 \% \mathrm{CO}_{2}$ at $37^{\circ} \mathrm{C}$. The immortalized human epidermal melanocyte PIG1 cells and immortalized vitiligo melanocyte PIG3V cells (both obtained from ATCC) were cultured in M154/HMGS medium (Invitrogen; Thermo Fisher Scientific, Inc.) supplemented with $0.25 \mu \mathrm{g} / \mathrm{ml}$ amphotericin $\mathrm{B}, 100 \mathrm{U} / \mathrm{ml}$ penicillin and $10 \mu \mathrm{g} / \mathrm{ml}$ neomycin (Invitrogen; Thermo Fisher Scientific, Inc.) in a humidified atmosphere of $5 \% \mathrm{CO}_{2}$ at $37^{\circ} \mathrm{C}$. For assessment of the effects of PM2.5 exposure on cells, the cells were incubated with PM2.5 $(0-200 \mu \mathrm{g} / \mathrm{ml})$ for $24 \mathrm{~h}$.

Short tandem repeat (STR) profiling. Authenticity of the human keratinocyte $\mathrm{HaCaT}$ cells was verified by performing STR analysis. DNA was prepared and suspended in double-distilled water, and then analyzed by STR profiling. The selected markers included the sex chromosome locus, amelogenin (Xp22.10-22.3 and Y) and eight core STR loci (CSF1PO; 5q33.3-34, D16S539; 16q24-qter, D13S317; 13q22-q31, D7S820; 7q, D5S818; 5q21-q31, TH01; 11p15.5, TPOX; 2p23-2pter, and vWA; 12p12-pter). The STR profiling result was compared with the STR profiles for $\mathrm{HaCaT}$ cell in the ATCC STR profiling database (https://www.atcc. org/en/STR_Database.aspx), and the results showed that STR profiles of $\mathrm{HaCaT}$ cells were identical to the STR profiles in the ATCC database. STR profiles of HaCaT cells were as follows: Amelogenin; XX, CSFIPO; 9 11, D16S539; 9 12, D13S317; 10 12, D7S820; 9 11, D5S818; 12 12, THOI; 9.3, TPOX; 11 12, and vWA; 1617.
Cell viability assay. Cell viability was measured using a Cell Counting Kit-8 (CCK-8; Guangzhou Yiyuan Biological Technology Co., Ltd.) according to the manufacturer's instruction. Cells were plated in a 96-well plate (at a cell density of $2.0 \times 10^{4}$ cells $\left./ \mathrm{ml}\right)$, and exposed to PM2.5 $(0-200 \mu \mathrm{g} / \mathrm{ml})$ for $24 \mathrm{~h}$. Zinc protoporphyrin IX (ZnPP; HO-1 inhibitor) and hemin chloride (Hemin; HO-1 agonist) were used to pre-incubate human melanocytes for $2 \mathrm{~h}$ at $37^{\circ} \mathrm{C}$ prior to PM2.5 exposure (200 $\mu \mathrm{g} / \mathrm{ml})$. The cells were then incubated with $10 \mu \mathrm{l}$ CCK-8 reagent for $2 \mathrm{~h}$, and then the absorbance was measured at $450 \mathrm{~nm}$ wavelength using a microplate reader (MRP-2100; Syntron).

Determination of SCF and bFGF levels. The secretions of SCF and bFGF in HaCaT cells were measured using specific SCF (cat. no. F02540) and bFGF (cat. no. F00760) ELISA kits, respectively, according to the manufacturer's instructions (Shanghai Westang Biotechnology Co., Ltd.). After the indicated treatment, the absorbance was measured at $450 \mathrm{~nm}$ wavelength using a microplate reader (MRP-2100; Syntron). The levels of SCF and bFGF were quantified according to the standard curve.

Determination of melanin contents. Melanin contents in PIG1 or PIG3V cells were detected with a $\mathrm{NaOH}$ method, as previously described (20). The cells were plated in a 6-well plate (at a cell density of $2 \times 10^{4}$ cells $\left./ \mathrm{ml}\right)$, and exposed to PM2.5 $(0-200 \mu \mathrm{g} / \mathrm{ml})$ for $24 \mathrm{~h}$. Then, the cells were washed with PBS three times and separated by $0.25 \%$ trypsin digestion. Cells were dissolved in $100 \mu \mathrm{l} \mathrm{NaOH}(1 \mathrm{M})$ for $1 \mathrm{~h}$ at $80^{\circ} \mathrm{C}$, then, centrifuged $(16,000 \mathrm{xg})$ for $20 \mathrm{~min}$ at room temperature. The supernatants were transferred to a 96-well plate, and the absorbance was measured at $405 \mathrm{~nm}$ wavelength using a microplate reader (MRP-2100; Syntron).

Tyrosinase activity assay. Tyrosinase activity in PIG1 or PIG3V cells was measured with a DOPA oxidase method, as previously described (21). The cells were plated in a 6-well plate (at a cell density of $2 \times 10^{4}$ cells $\left./ \mathrm{ml}\right)$ and exposed to PM2.5 $(0-200 \mu \mathrm{g} / \mathrm{ml})$ for $24 \mathrm{~h}$. Then cells were washed with PBS three times, lysed with $1 \%$ Triton X-100 and centrifuged $(16,000 \mathrm{x} \mathrm{g})$ at room temperature for $15 \mathrm{~min}$. The supernatants were transferred to a 96-well plate and $100 \mu 11 \% \mathrm{~L}$-DOPA was added for $1 \mathrm{~h}$ at $37^{\circ} \mathrm{C}$. The absorbance was measured at $490 \mathrm{~nm}$ wavelength using a microplate reader (MRP-2100; Syntron).

Cell apoptosis. Cell apoptosis was assessed by Annexin V-FITC/Propidium Iodide (PI) double staining using a cell apoptosis detection kit (Nanjing KeyGen Biotech Co., Ltd.) as previously described (16). After the indicated treatment, PIG1 and PIG3V cells were collected by centrifugation $(500 \mathrm{x} \mathrm{g}$ for $5 \mathrm{~min}$ at $4^{\circ} \mathrm{C}$ ). Then, the cells were washed with ice-cold PBS three times and suspended in binding buffer. Finally, the cells were incubated with annexin V-FITC and PI for $15 \mathrm{~min}$ at room temperature in the dark, and the apoptotic cells were counted using a flow cytometer (BD Biosciences). The cell apoptotic ratio was subsequently analyzed using WinMDI v2.9 software (The Scripps Research Institute).

Cell migration. Cell migration was evaluated by a transwell assay, as previously described (20). PIG1 or PIG3V cells were exposed to PM2.5 $(0,25,50,100$ and $200 \mu \mathrm{g} / \mathrm{ml})$ for $24 \mathrm{~h}$. Cells 
( $2 \times 10^{5}$ cells $/ \mathrm{ml} ; 100 \mu 1$ serum-free cell suspension) were added into the upper chamber of the transwell insert (Corning, Inc.) and $600 \mu 1 \mathrm{M} 154 / \mathrm{HMGS}$ medium (Invitrogen; Thermo Fisher Scientific, Inc.) supplemented with 20\% FBS (Gibco; Thermo Fisher Scientific, Inc.) was added into the lower chamber. After incubation for $24 \mathrm{~h}$, the transwell insert was removed from the plate. The unmigrated cells in the upper chamber were carefully removed using a cotton-tipped applicator. The migrated cells were fixed with $70 \%$ ethanol for $10 \mathrm{~min}$ at room temperature and stained with $0.2 \%$ crystal violet for $10 \mathrm{~min}$ at room temperature. The excess crystal violet was discarded, then the cells were washed and counted in five different fields of view under an inverted light microscope (magnification, $\mathrm{x} 400$; Olympus Corporation) to get an average cell migration rate.

Determination of malondialdehyde (MDA), superoxide dismutase (SOD) and glutathione peroxidase (GSH-Px) levels. MDA contents, SOD and GSH-Px levels were measured using specific MDA (cat. no. 10009055), SOD (cat. no. 706002) and GSH-Px (cat. no. 703102) assay kits, respectively, according to the manufacturer's instructions (Cayman Chemical). After the indicated treatment, the absorbance was measured at $490 \mathrm{~nm}$ wavelength using a microplate reader (MRP-2100; Syntron) and quantified according to the standard curve. MDA content is presented as $\mathrm{nmol} / \mathrm{mg}$ protein, SOD activity is presented as $\mathrm{U} / \mathrm{mg}$ protein and GSH-Px activity is presented as $\mathrm{U} / \mathrm{g}$ protein.

Total and nuclear protein isolation. Total protein was isolated using a RIPA kit (Beyotime Institute of Biotechnology) according to the manufacturer's instruction. After treatment, the cells were washed with ice-cold PBS three times and lysed with RIPA lysis buffer for $40 \mathrm{~min}$. Then total protein was collected by centrifugation $(12,000 \mathrm{x} \mathrm{g})$ for $12 \mathrm{~min}$ at $4{ }^{\circ} \mathrm{C}$ and stored at $-80^{\circ} \mathrm{C}$ for the following experiments. Nuclear protein was isolated using a Scientific NE-PER nuclear extraction kit (Thermo Fisher Scientific, Inc.), according to the manufacturer's instruction. After treatment, the cells were washed with ice-cold PBS three times and incubated with NE-PER Nuclear lysis buffer for $10 \mathrm{~min}$. Then, the nuclear protein was collected by centrifugation $\left(15,000 \mathrm{xg}\right.$ ) for $10 \mathrm{~min}$ at $4^{\circ} \mathrm{C}$ and stored at $-80^{\circ} \mathrm{C}$ for the following experiments.

Western blot analysis. A western blotting assay was performed to analyze the related protein expression, as previously described (16). Protein concentration was determined by a BCA assay (Beyotime Institute of Biotechnology). In total, $60 \mu \mathrm{g}$ total protein or nuclear protein of each sample was denatured for 5 min at $95^{\circ} \mathrm{C}$ and separated by SDS-PAGE on 8-12\% gels. After the separated protein was transferred onto PVDF membranes (EMD Millipore) and blocked with 5\% skim milk for $120 \mathrm{~min}$ at room temperature, the PVDF membranes were incubated with primary antibodies according to manufacturer's instruction at $4^{\circ} \mathrm{C}$ overnight. After rewarming, the PVDF membranes were washed with PBS three times for $5 \mathrm{~min}$, and incubated with horse-radish peroxidase (HRP) conjugated Rabbit Anti-Mouse IgG H\&R (1:1,000; cat. no. ab6728; Abcam) or Goat Anti-Rabbit IgG H\&R HRP conjugated (1:1,000; cat. no. ab6721; Abcam) for $1 \mathrm{~h}$ at room temperature. Blots of target protein were developed with enhanced chemiluminescence substrates (Guangzhou Ladder Biotech. Co. Ltd.) and visualized with exposure to X-ray film (Kodak). Integrated optical density of target bands was accurately determined using the ImageJ $1.48 \mathrm{u}$ analysis system (National Institutes of Health). In the present study, antibodies against cytochrome C (1:200; cat. no. ab90529) and CoxIV (1:500; cat. no. ab153709) were purchased from Abcam, antibodies against $\beta$-actin (1:1,000; cat. no. 4967), cleaved caspase 3 (1:1,000; cat. no. 9661) and caspase 3 (1:1,000; cat. no. 9662) were purchased from Cell Signaling Technology, Inc., and antibodies against Nrf2 (1:1,000; cat. no. sc-365949), H3 (1:1,000; cat. no. sc-376769) and HO-1 (1:1,000; cat. no. sc-136960) were purchased from Santa Cruz Biotechnology, Inc.

Statistical analysis. Data from six independent experiments were presented as the mean value \pm standard deviation. Statistical significance was performed by one-way ANOVA followed by the Bonferroni multiple comparison test using SPSS 21.0 software (SPSS, Inc.). P<0.05 was considered to indicate a statistically significant difference.

\section{Results}

PM2.5 exposure inhibits cell viability, and downregulates the production of bFGF and SCF in human keratinocytes. The effect of PM2.5 on HaCaT cell survival was firstly determined; HaCaT cells were exposed to PM2.5 $(0-200 \mu \mathrm{g} / \mathrm{ml})$ for $24 \mathrm{~h}$, and then cell viability was detected by a CCK- 8 assay. PM2.5 exposure significantly decreased $\mathrm{HaCaT}$ cell viability in a dose-dependent manner from $50 \mu \mathrm{g} / \mathrm{ml}$ PM2.5 (Fig. 1A). Furthermore, the secretions of SCF and bFGF in HaCaT cells after PM2.5 exposure for $24 \mathrm{~h}$ were evaluated. PM2.5 exposure significantly inhibited the secretions of SCF and bFGF in $\mathrm{HaCaT}$ cells in a dose-dependent manner from $50 \mu \mathrm{g} / \mathrm{ml}$ PM2.5 (Fig. 1B and C).

PM2.5 exposure attenuates the melanization process in human melanocytes. The effectiveness of the melanization process was estimated by measuring the melanin contents and cellular tyrosinase activity in melanocytes after PM2.5 $(0-200 \mu \mathrm{g} / \mathrm{ml})$ exposure for $24 \mathrm{~h}$. PM2.5 exposure significantly inhibited the melanin contents and tyrosinase activity in both PIG1 and PIG3V cells in a dose-dependent manner from $50 \mu \mathrm{g} / \mathrm{ml}$ PM2.5 (Fig. 2). These data demonstrated that PM2.5 had a negative effect on the melanization process in human melanocytes.

PM2.5 exposure induces apoptosis in human melanocytes. PIG1 or PIG3V cells were exposed to PM2.5 $(0-200 \mu \mathrm{g} / \mathrm{ml})$ for $24 \mathrm{~h}$, then the cell viability was detected by a CCK- 8 assay. PM2.5 exposure significantly decreased cell viability in both PIG1 (Fig. 3A) and PIG3V (Fig. 3B) cells in a dose-dependent manner from $50 \mu \mathrm{g} / \mathrm{ml}$ PM2.5. PIG1 or PIG3V cells were exposed to PM2.5 $(0-200 \mu \mathrm{g} / \mathrm{ml})$ for $24 \mathrm{~h}$, and the extent of apoptosis was quantified by AnnexinV-FITC/PI double staining by flow cytometry. Apoptosis was significantly increased in both PIG1 (Fig. 3C) and PIG3V (Fig. 3D) cells after PM2.5 exposure. The present results demonstrated that PM2.5 was able to facilitate cell apoptosis in human melanocytes.

The mitochondrial apoptotic pathway is the major pathway for cell apoptosis activated by various cytotoxic substances (22). Therefore, the present study examined the changes of cytochrome 

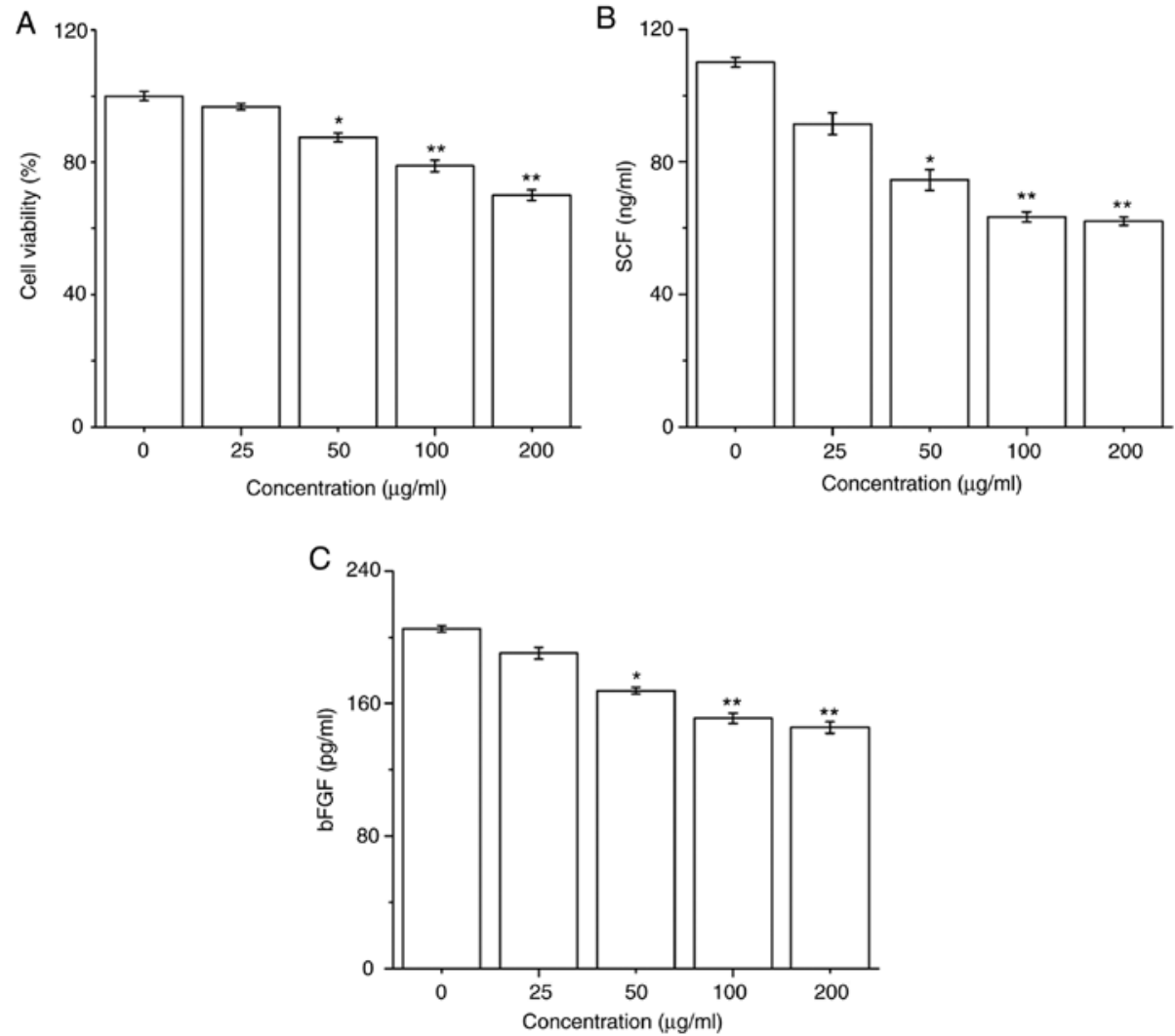

Figure 1.Effect of PM2.5 exposure on cell viability and the secretions of SCF and bFGF in human keratinocyte HaCaT cells. Cells were exposed to (0-200 $\mu \mathrm{g} / \mathrm{ml})$ PM2.5 for $24 \mathrm{~h}$, cell viability was measured by Cell Counting Kit- 8 assay, and the secretions of SCF and bFGF were evaluated by ELISA. (A) PM2.5 exposure decreased cell viability in $\mathrm{HaCaT}$ cells in a dose-dependent manner. (B) PM2.5 exposure inhibited the secretion of SCF in HaCaT cells in a dose-dependent manner. (C) PM2.5 exposure inhibited the secretion of bFGF in HaCaT cells in a dose-dependent manner. Data are presented as the mean \pm SD. $n=6$. ${ }^{*} \mathrm{P}<0.05$, ${ }^{* *} \mathrm{P}<0.01$ vs. $0 \mu \mathrm{g} / \mathrm{ml}$ PM2.5. PM2.5, particulate matter 2.5; SCF, stem cell factor; bFGF, basic fibroblast growth factor.

A<smiles>[TeH4]</smiles>

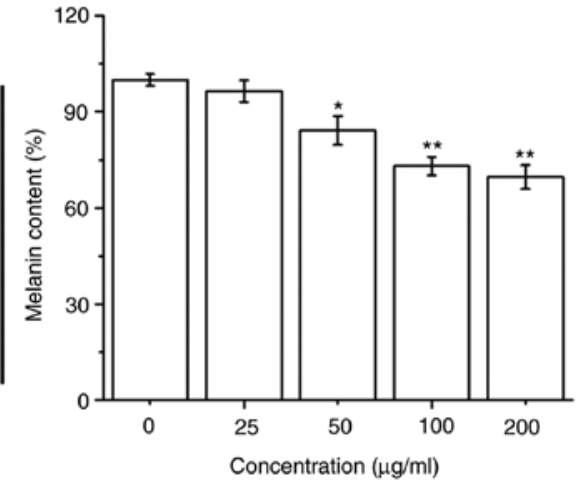

B

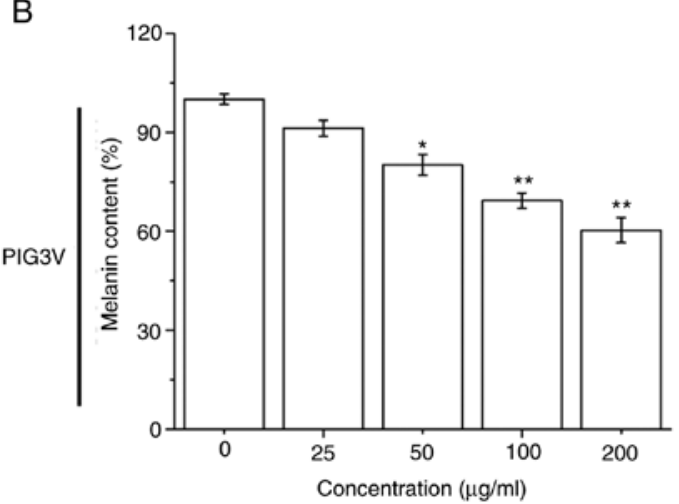

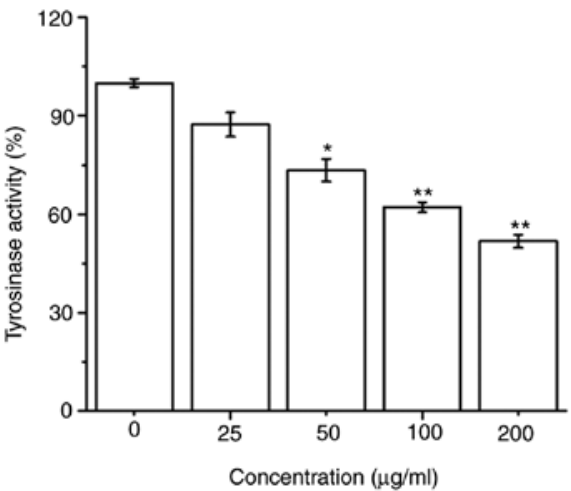

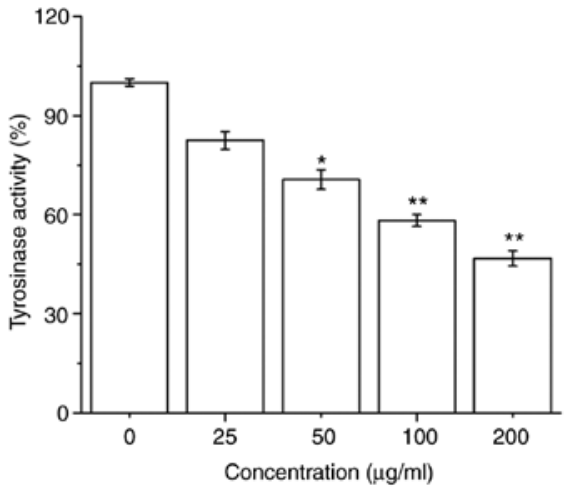

Figure 2. PM2.5 exposure attenuates the melanization process in human melanocytes. (A) PIG1 or (B) PIG3V cells were exposed to (0-200 $\mu \mathrm{g} / \mathrm{ml})$ PM2.5 for $24 \mathrm{~h}$, then the melanin contents were measured using a $\mathrm{NaOH}$ method and cellular tyrosinase activities were measured using a DOPA oxidase method. Data are presented as the mean $\pm \mathrm{SD} . \mathrm{n}=6 .{ }^{*} \mathrm{P}<0.05,{ }^{* *} \mathrm{P}<0.01 \mathrm{vs} .0 \mu \mathrm{g} / \mathrm{ml} \mathrm{PM} 2.5$. PM2.5, particulate matter 2.5 . 

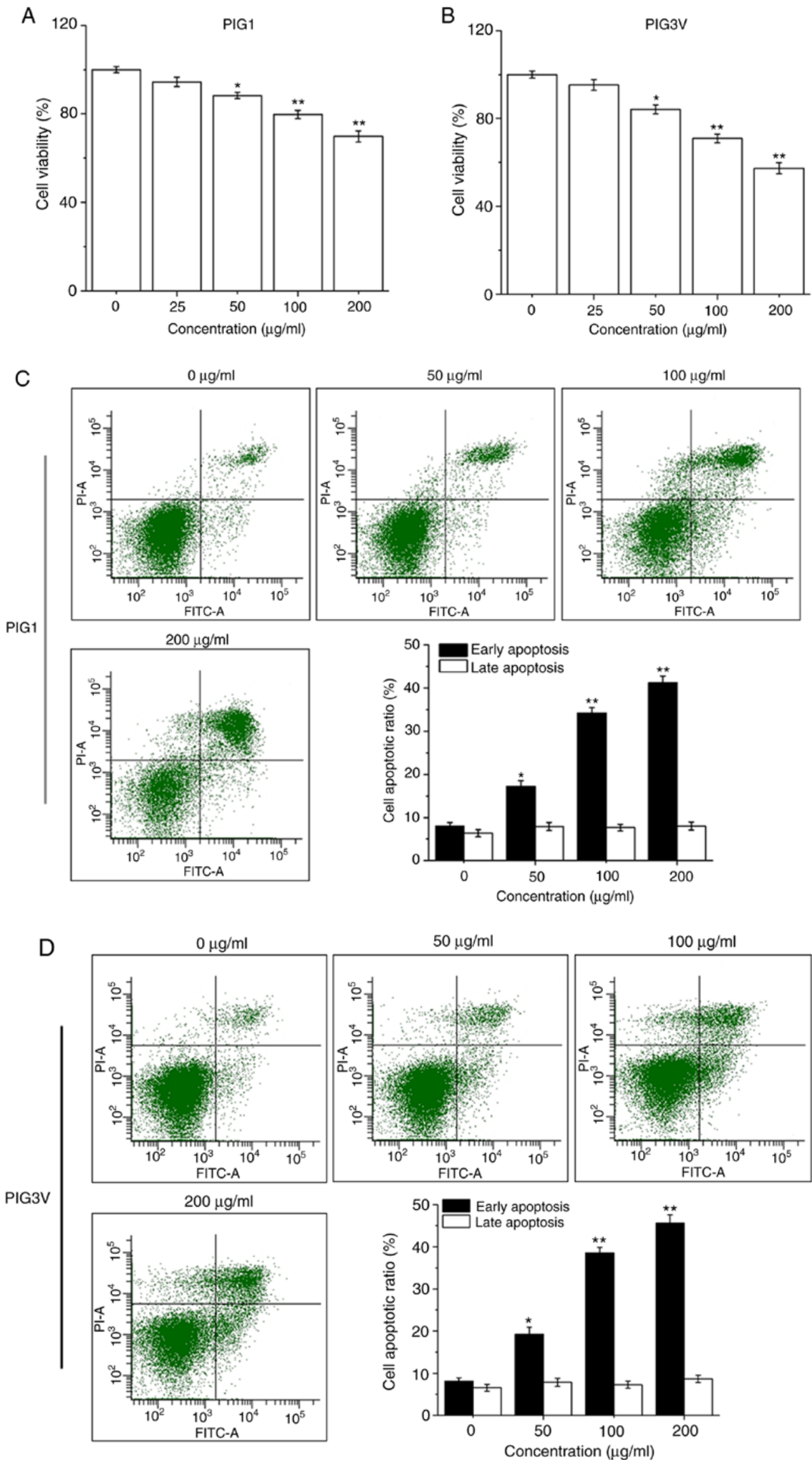

Figure 3. PM2.5 exposure induces cell apoptosis in human melanocytes. PIG1 or PIG3V cells were exposed to (0-200 $\mu \mathrm{g} / \mathrm{ml})$ PM2.5 for $24 \mathrm{~h}$. Cell viability was measured by Cell Counting Kit-8 assay, cell apoptosis was evaluated by AnnexinV-FITC/PI double staining, and the expressions of apoptosis related-proteins were determined by western blotting. PM2.5 exposure decreased (A) PIG1 and (B) PIG3V cell viability in a dose-dependent manner. PM2.5 exposure increased cell apoptosis in (C) PIG1 and (D) PIG3V cells. Data are presented as the mean \pm SD. $\mathrm{n}=6 .{ }^{*} \mathrm{P}<0.05,{ }^{* *} \mathrm{P}<0.01$ vs. respective $0 \mu \mathrm{g} / \mathrm{ml} \mathrm{PM} 2.5$. 
E

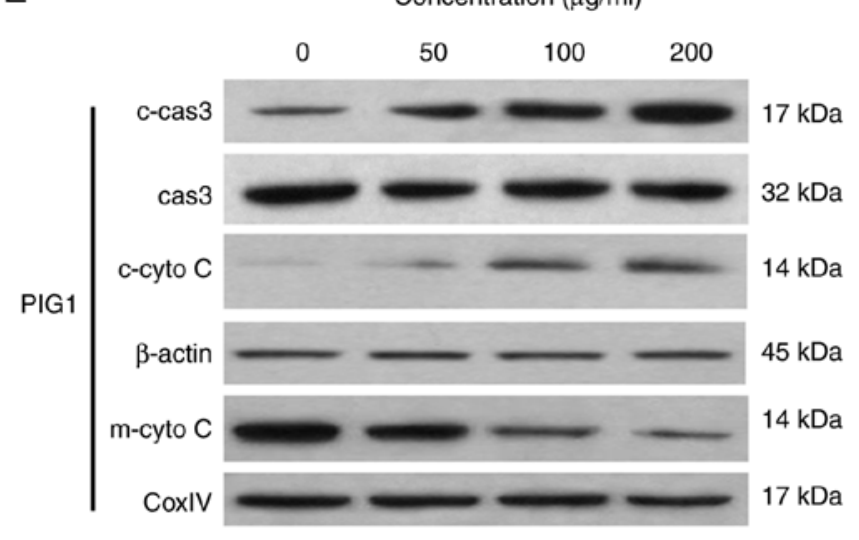

$\mathrm{F}$

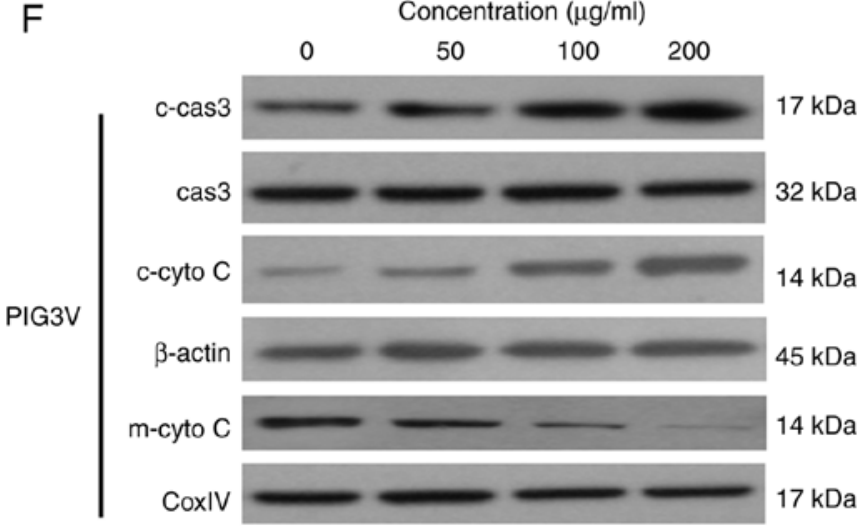

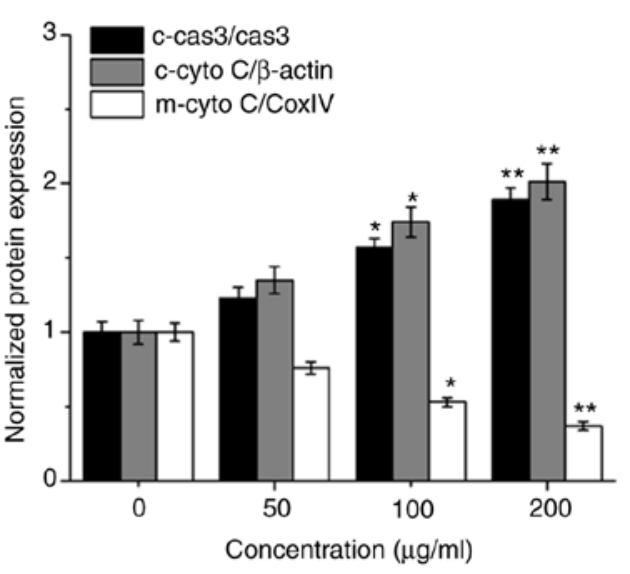

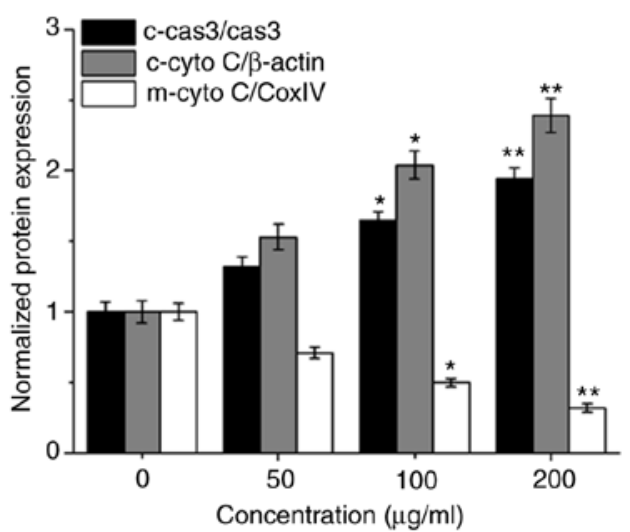

Figure 3. Continued. PM2.5 exposure induces cell apoptosis in human melanocytes. PIG1 or PIG3V cells were exposed to (0-200 $\mu$ g/ml) PM2.5 for 24 h. Cell viability was measured by Cell Counting Kit- 8 assay, cell apoptosis was evaluated by AnnexinV-FITC/PI double staining, and the expressions of apoptosis related-proteins were determined by western blotting. PM2.5 exposure regulated the expressions of apoptosis-related molecules in (E) PIG1 and (F) PIG3V cells. The changes of cytochrome $\mathrm{C}$ and the activation of caspase 3 were detected by western blotting. Data are presented as the mean $\pm \mathrm{SD}$. $\mathrm{n}=6$. ${ }^{*} \mathrm{P}<0.05$, ${ }^{* *} \mathrm{P}<0.01$ vs. respective $0 \mu \mathrm{g} / \mathrm{ml} \mathrm{PM} 2.5$. PM2.5, particulate matter 2.5; c-cas3, cleaved caspase3; cas3, caspase3; c-cyto C, cytosolic cytochrome C; m-cyto C, mitochondria cytochrome C; PI, propidium iodide.

$\mathrm{C}$ and the activation of caspase 3 in the model used in the present study. After PIG1 or PIG3V cells were exposed to PM2.5 (0, 50, 100 and $200 \mu \mathrm{g} / \mathrm{ml}$ ) for $24 \mathrm{~h}$, a western blotting assay was used to evaluate the changes of cytochrome $\mathrm{C}$ and the activation of caspase 3. PM2.5 exposure promoted the protein expressions of cleaved caspase 3 and cytosolic cytochrome $\mathrm{C}$, while the expression of mitochondria cytochrome $\mathrm{C}$ was decreased in both PIG1 (Fig. 3E) and PIG3V (Fig. 3F) cells. These data suggested that the mitochondrial apoptotic pathway may be involved in PM2.5-elicited apoptosis in human melanocytes.

PM2.5 inhibits human melanocyte migration. To examine the effect of PM2.5 on the biological characteristics of human melanocytes, the present study further examined its effect on PIG1 and PIG3V cells migration by a transwell assay. The cell migration was significantly decreased after PIG1 cells were exposed to $\geq 50 \mu \mathrm{g} / \mathrm{ml}$ PM2 .5 for $24 \mathrm{~h}$ (Fig. 4A) and PIG3V cells were exposed to $\geq 25 \mu \mathrm{g} / \mathrm{ml}$ PM2.5 for $24 \mathrm{~h}$ (Fig. 4B). These data demonstrated that PM2.5 inhibited cell migration in human melanocytes.

PM2.5 induces the oxidative stress response in human melanocytes. Oxidative stress plays an important role in cell injury. MDA, SOD and GSH-Px represent the status of oxidative stress (23). The present data showed that PM2.5 exposure suppressed the activities of SOD and GSH-Px, while enhancing MDA contents in both PIG1 (Fig. 5A) and PIG3V (Fig. 5B) cells in a concentration-dependent manner. These data suggested that the oxidative stress response may be responsible for PM2.5-elicited apoptosis in human melanocytes.

The Nrf2 pathway plays an important role in the defense against oxidative stress injury (24). Therefore, the protein expressions of Nrf2 (nuclear), Nrf2 (total) and its downstream molecule HO-1 in human melanocytes were analyzed to determine its role in PM2.5-induced oxidative stress injury. As shown in Fig. 5C, after PM2.5 (0, 50, 100 and $200 \mu \mathrm{g} / \mathrm{ml})$ exposure, the protein expressions of Nrf2 (nuclear) and $\mathrm{HO}-1$ were significantly increased in PIG1 cells. Only $200 \mu \mathrm{g} / \mathrm{ml}$ PM2.5 exposure could lead to a significant upregulation of Nrf2 (nuclear) and HO-1 expression in PIG3V cells (Fig. 5D).

HO-1 is responsible for PM2.5-induced human melanocyte oxidative stress injury. To further verify that $\mathrm{HO}-1$ induction is responsible for the antioxidant response in human melanocytes, zinc protoporphyrin IX (ZnPP, a HO-1 inhibitor) and hemin chloride (Hemin, a HO-1 agonist) were used to pre-incubate human melanocytes for $2 \mathrm{~h}$ before PM2.5 exposure (Fig. 6A and B). As presented in Fig. 6A and B, ZnPP pre-incubation inhibited the expression of HO-1, while Hemin 


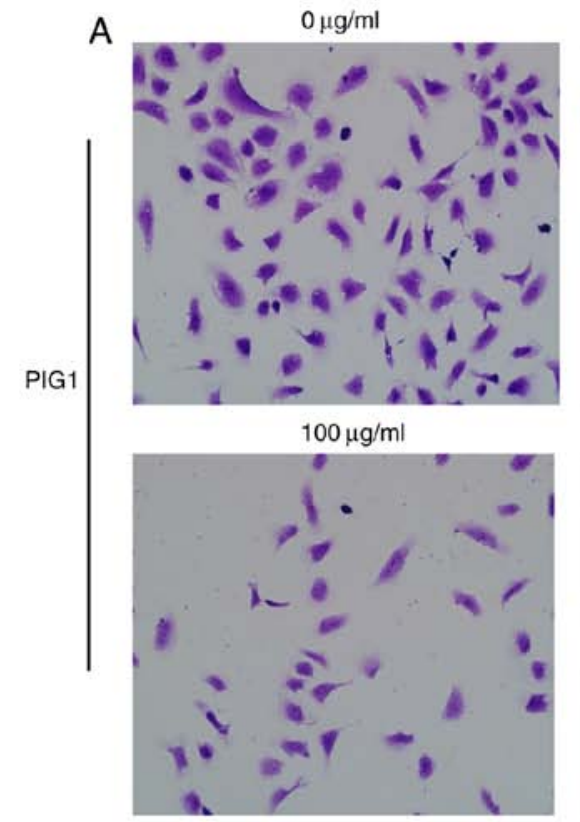

B
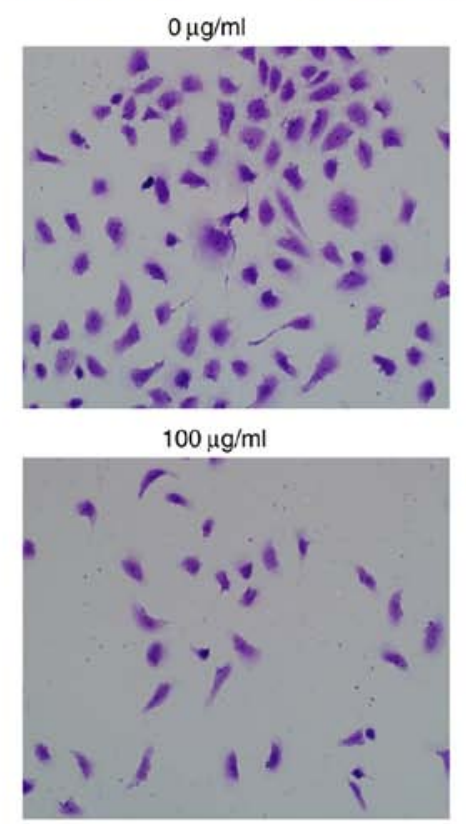
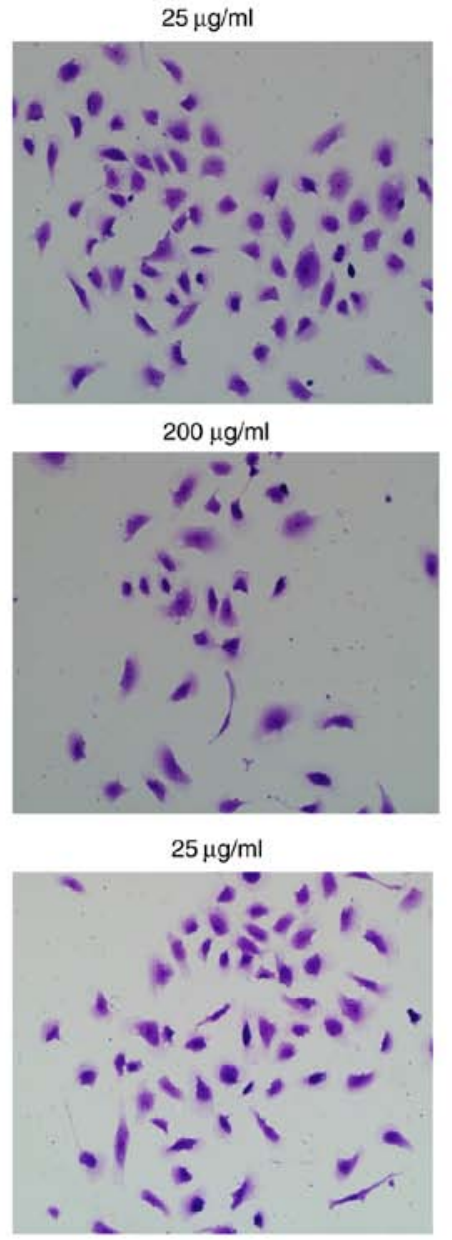

$200 \mu \mathrm{g} / \mathrm{ml}$

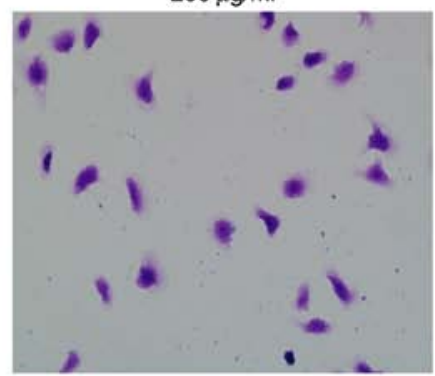

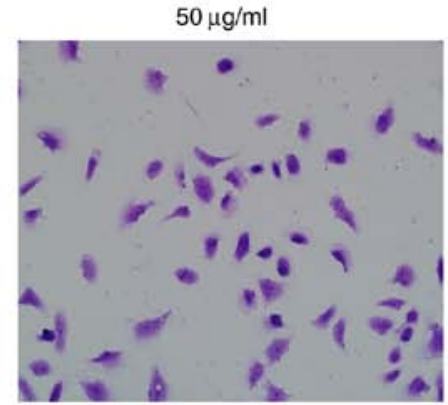
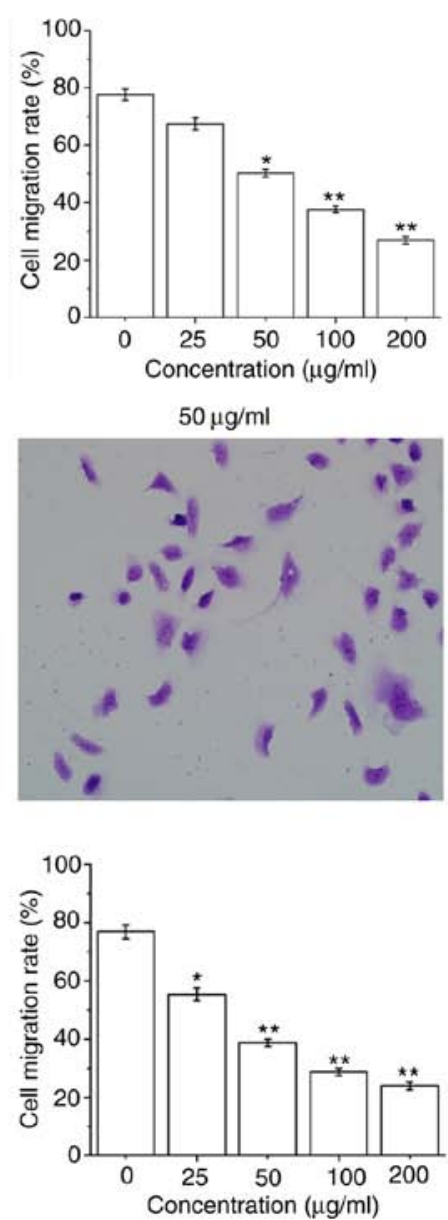

Figure 4. PM2.5 exposure inhibits cell migration in human melanocytes. (A) PIG1 or (B) PIG3V cells were exposed to (0-200 $\mu \mathrm{g} / \mathrm{ml})$ PM2.5 for $24 \mathrm{~h}$, then cell migration was examined by transwell assay (magnification, $\mathrm{x} 400$ ). Data are presented as the mean $\pm \mathrm{SD}$. $\mathrm{n}=6 .{ }^{*} \mathrm{P}<0.05,{ }^{* * *} \mathrm{P}<0.01 \mathrm{vs} .0 \mu \mathrm{g} / \mathrm{ml} \mathrm{PM} 2.5$. $\mathrm{PM} 2.5$, particulate matter 2.5 .

pre-incubation promoted the expression of HO-1. Cell viability detection data showed that both $\mathrm{ZnPP}$ and Hemin had no toxic effect in human melanocytes. Compared with the PM2.5 exposure alone, ZnPP pre-incubation exacerbated the injury induced by PM2.5 exposure, while Hemin pre-incubation enhanced cell viability in both PIG1 (Fig. 6C) and PIG3V (Fig. 6D) cells. The cell apoptosis detection data showed that ZnPP pre-incubation exacerbated PM2.5-induced cell apoptosis, while Hemin pre-incubation partly reversed PM2.5-induced cell apoptosis in both PIG1 (Fig. 6E) and PIG3V (Fig. 6F) cells.

The status of oxidative stress was also measured in human melanocytes. As shown in Fig. 7, compared with the PM2.5 exposure alone, ZnPP pre-incubation significantly increased the MDA contents, and decreased the SOD and GSH-Px activity in both PIG1 and PIG3V cells. Conversely, compared with the PM2.5 exposure alone Hemin pre-incubation significantly decreased the MDA contents, and increased the SOD and GSH-Px activity in both PIG1 and PIG3V cells. All these results suggested that HO-1 could protect human melanocytes against PM2.5-induced oxidative stress injury and cell death in human melanocytes.

\section{Discussion}

There is an association between vitiligo and intrinsic defects within melanocytes (2). Intrinsic defects within melanocytes can activate the cellular oxidative stress response (25). PM2.5 is known for its toxic effects on skin, cardiovascular and respiration systems $(6,9,11)$. However, to the best of the authors' knowledge, the effects and mechanisms of PM2.5 on vitiligo 

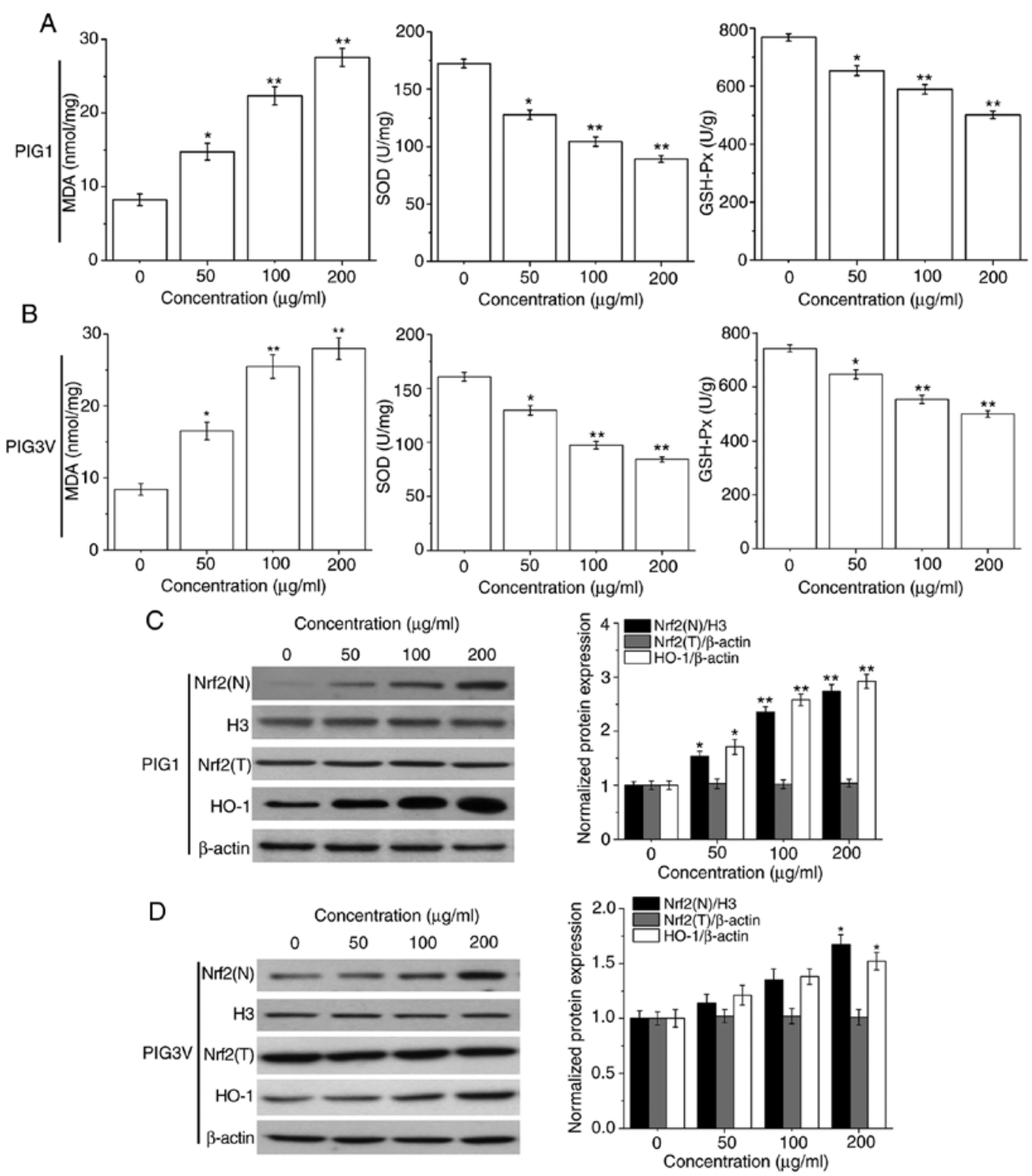

Figure 5. PM2.5 exposure induces the oxidative stress response and affects the activation of the Nrf2 pathway in human melanocytes. PIG1 or PIG3V cells were exposed to $(0-200 \mu \mathrm{g} / \mathrm{ml})$ PM2 .5 for $24 \mathrm{~h}$, and MDA contents, SOD and GSH-Px levels were measured using specific respective MDA, SOD and GSH-Px assay kits. The Nrf2 pathway related-protein expressions were determined by western blotting. PM2.5 exposure suppressed the activities of SOD and GSH-Px, while enhancing MDA contents in both (A) PIG1 and (B) PIG3V cells. PM2.5 exposure activated the Nrf2 pathway in (C) PIG1 cells, while only a high concentration $(200 \mu \mathrm{g} / \mathrm{ml})$ of PM2.5 exposure could significantly promote the expression of Nrf2(N) and HO-1 in (D) PIG3V cells. Data are presented as the mean \pm SD. $\mathrm{n}=6$. ${ }^{*} \mathrm{P}<0.05,{ }^{* *} \mathrm{P}<0.01$ vs. respective $0 \mu \mathrm{g} / \mathrm{ml}$ PM2.5. PM2.5, particulate matter 2.5; MDA, malondialdehyde; GSH-Px, glutathione peroxidase; SOD, superoxide dismutase; Nrf2, nuclear factor erythroid 2-related factor 2; HO-1, heme oxygenase-1; $\mathrm{N}$, nuclear; $\mathrm{T}$, total.

are not fully elucidated. The present study aimed to clarify the effects of PM2.5 exposure on cell viability, and the secretions of SCF and bFGF in $\mathrm{HaCaT}$ cells, and cell migration, apoptosis and oxidative stress injury in PIG1 cells and PIG3V cells. The present study demonstrated that PM2.5 exposure significantly decreased cell viability of HaCaT cells, PIG1 cells and PIG3V cells in a dose-dependent manner, and decreased secretions of SCF and bFGF in HaCaT cells. The present study additionally demonstrated the PM2.5 exposure inhibited cell migration, and promoted apoptosis and oxidative stress injury in PIG1 cells and PIG3V cells.

The main pathological features of vitiligo are the destruction or apoptosis of melanocytes (3). Therefore, in the present study, two types of human melanocytes (PIG1 and
PIG3V cells) were selected to evaluate the effect of PM2.5 exposure on human melanocyte apoptosis. The present results showed that PM2.5 exposure was able to promote apoptosis in human melanocytes. Cell apoptosis has two important pathways: Death receptor-mediated exogenous apoptotic pathways and mitochondrial/cytochrome $\mathrm{C}$-mediated endogenous apoptotic pathways $(26,27)$. In the present study, the mechanisms of PM2.5 exposure on cytochrome $\mathrm{C}$ release were examined. The present results showed that PM2.5 exposure promoted cytochrome $\mathrm{C}$ release into the cytoplasm in both PIG1 and PIG3V cells. It was hypothesized that the activation of caspase 3 is the central link of cell apoptosis (28). The present data further demonstrated that PM2.5 exposure induced caspase 3 activation in PIG1 and PIG3V cells. Collectively, these results 


\section{A}

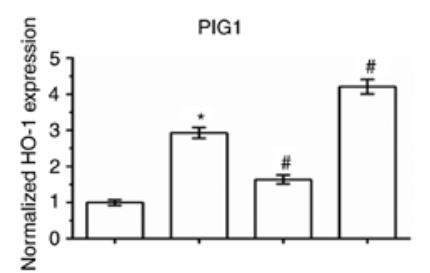

PM2.5 $(200 \mu \mathrm{g} / \mathrm{ml}) \quad-\quad+\quad+\quad+\quad+$ $\mathrm{ZnPP}(10 \mu \mathrm{M})$

Hemin $(10 \mu \mathrm{M})$

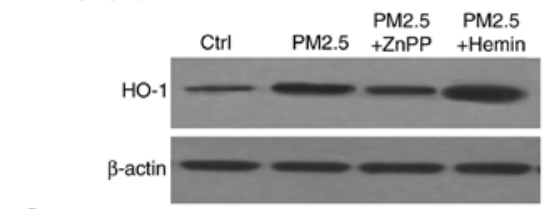

C

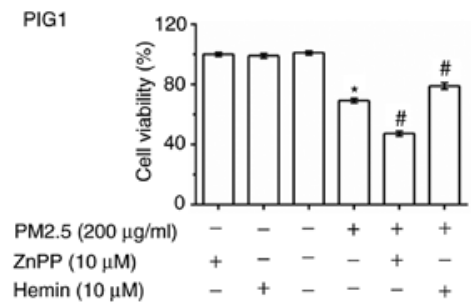

B

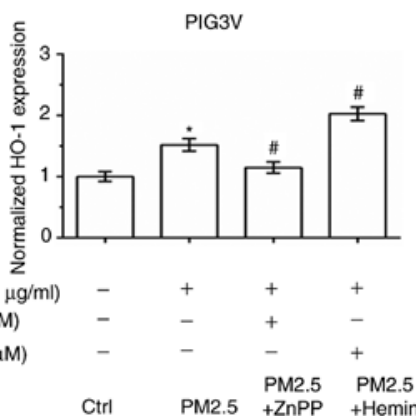

$\begin{array}{lllll}\operatorname{PM} 2.5(200 \mu \mathrm{g} / \mathrm{ml}) & - & + & + & + \\ \mathrm{ZnPP}(10 \mu \mathrm{M}) & - & - & + & - \\ \text { Hemin }(10 \mu \mathrm{M}) & - & - & - & + \\ & & & \text { PM2.5 } & \text { PM2.5 } \\ & \text { Ctrl } & \text { PM2.5 } & +\mathrm{ZnPP} & + \text { Hemin }\end{array}$

$\mathrm{HO}-1$

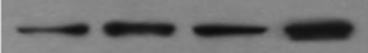

D

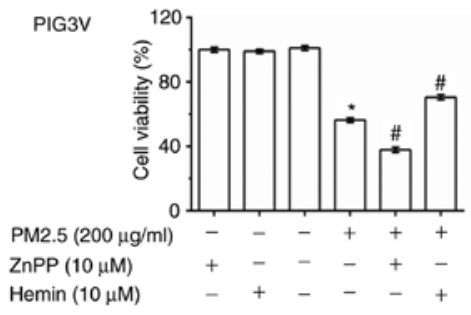

E

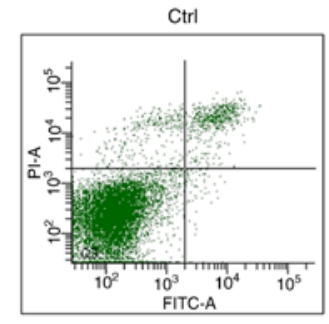

PIG1

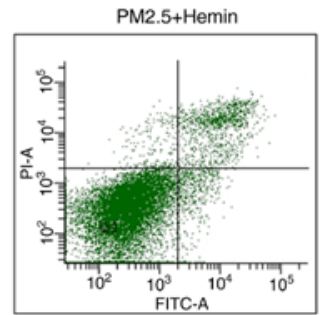

$\mathrm{F}$

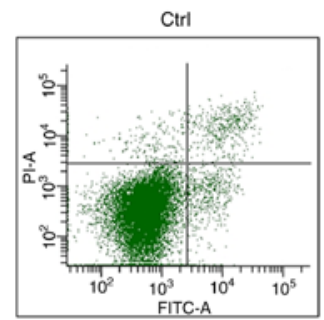

PIG3V

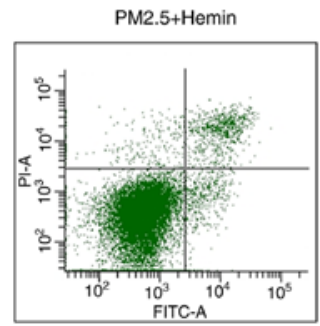

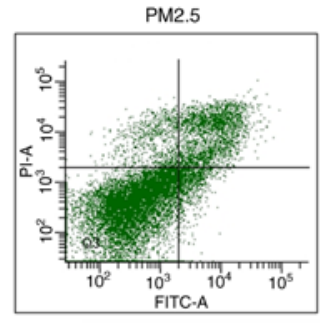

Early apoptosis

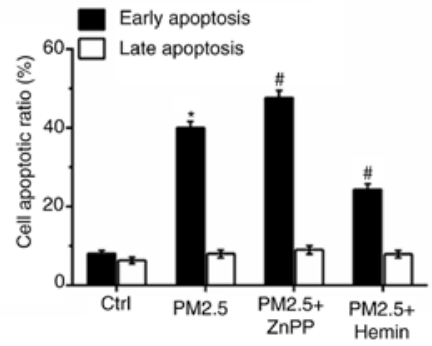

PM2.5
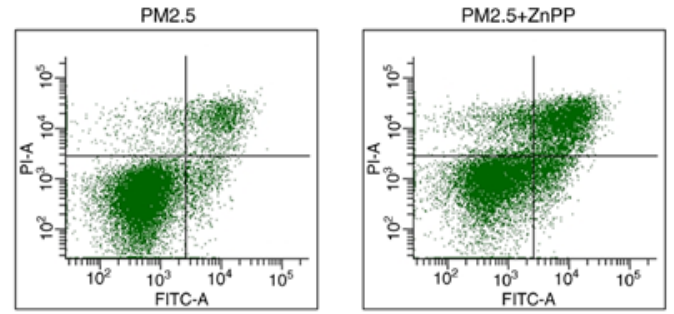

Early apoptosis

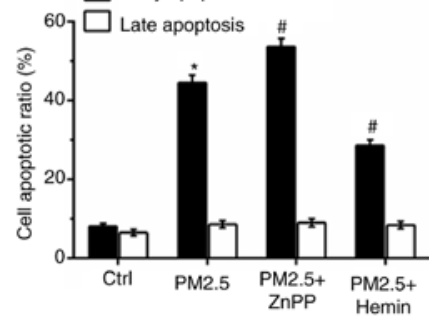

Figure 6. Effect of HO-1 on PM2.5 exposure-induced cell apoptosis in human melanocytes. PIG1 or PIG3V cells were pretreated with $10 \mu \mathrm{M}$ ZnPP or $10 \mu \mathrm{M}$ Hemin for $2 \mathrm{~h}$ prior to incubation with (200 $\mu \mathrm{g} / \mathrm{ml})$ PM2.5 for $24 \mathrm{~h}$. HO-1 expressions in (A) PIG1 and (B) PIG3V cells. Effects of HO-1 on the reduction of cell viability induced by PM2.5 in (C) PIG1 and (D) PIG3V cells. ${ }^{*} \mathrm{P}<0.05$ vs. $0 \mu \mathrm{g} / \mathrm{ml}$ PM2.5, ${ }^{*} \mathrm{P}<0.05$ vs. $200 \mu \mathrm{g} / \mathrm{ml}$ PM2.5. Effects of HO-1 on PM2.5 induced cell apoptosis in (E) PIG1 and (F) PIG3V cells. Data are presented as the mean \pm SD. $n=6$. "P<0.05 vs. respective Ctrl; " $\mathrm{P}<0.05$ vs. PM2.5. PM2.5, particulate matter 2.5; HO-1, heme oxygenase-1; ZnPP, Zinc protoporphyrin; Hemin, hemin chloride; Ctrl, control; PI, propidium iodide. 

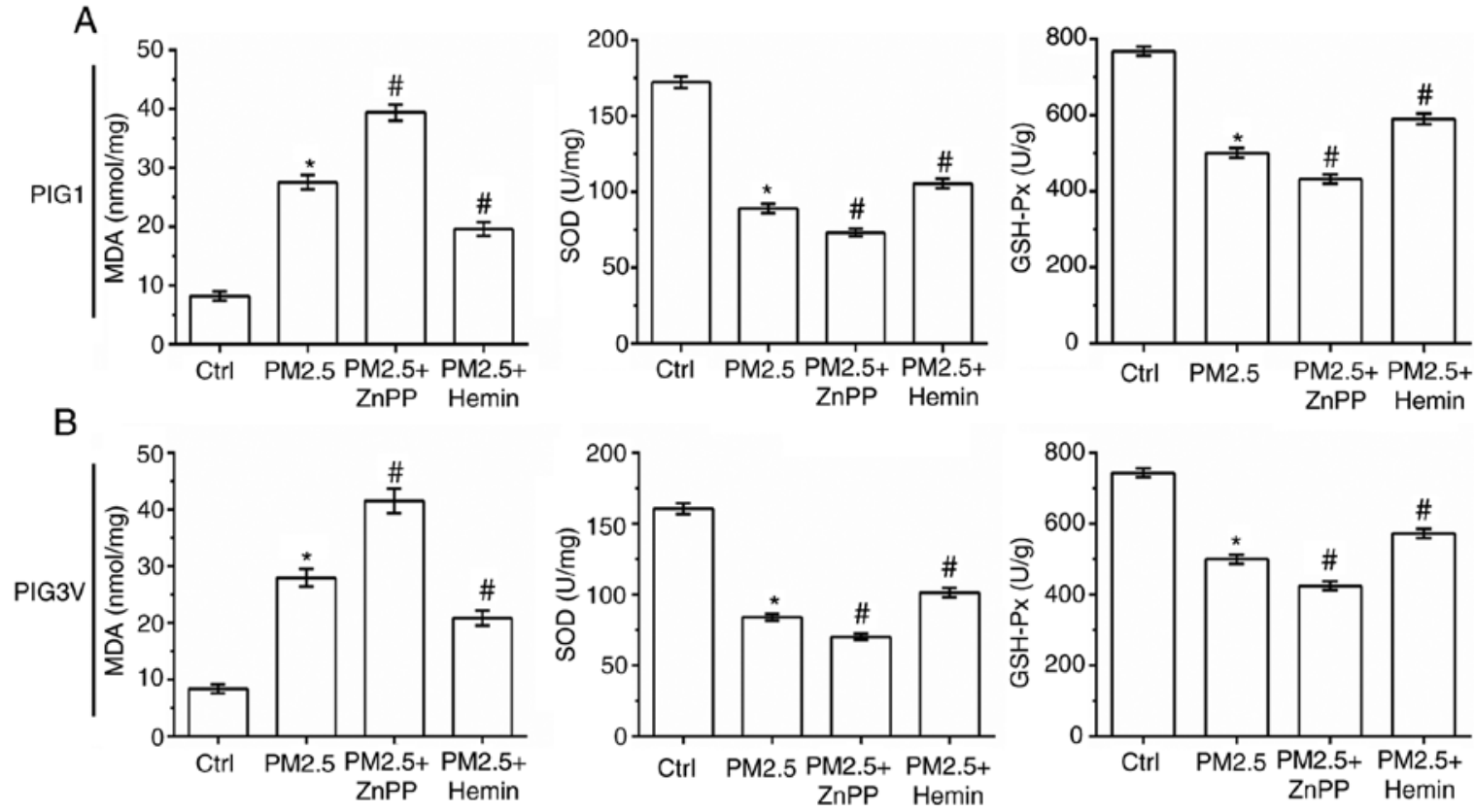

Figure 7. Effect of heme oygenase-1 on PM2.5 exposure induced oxidative stress response in human melanocytes. PIG1 or PIG3V cells were pretreated with $10 \mu \mathrm{M}$ ZnPP or $10 \mu \mathrm{M}$ Hemin for $2 \mathrm{~h}$ prior to incubation with $200 \mu \mathrm{g} / \mathrm{ml}$ PM2.5 for $24 \mathrm{~h}$. MDA contents, and SOD and GSH-Px activity in (A) PIG1 and (B) PIG3V cells. Data are presented as the mean \pm SD. $n=6 .{ }^{*} \mathrm{P}<0.05$ vs. Ctrl; ${ }^{\text {}} \mathrm{P}<0.05$ vs. PM2.5. PM2.5, particulate matter 2.5 ; MDA, malondialdehyde; GSH-Px, glutathione peroxidase; SOD, superoxide dismutase; ZnPP, zinc protoporphyrin; Hemin, hemin chloride; Ctrl, control.

suggested that PM2.5 induced human melanocyte apoptosis through release of cytochrome $\mathrm{C}$ and activation of caspase 3 .

Oxidative stress caused by reactive oxygen species (ROS) is an important part of cell apoptosis $(29,30)$. Previous studies have demonstrated that oxidative stress injury is activated in vitiligo $(25,31)$. In addition, previous studies on the toxic effect of PM2.5 demonstrated that PM2.5 is a major carrier for some organic chemicals, which can be localized in mitochondria and reduce SOD generation $(11,32)$. SOD is a scavenger of endogenous ROS. A reduction of SOD activity not only results in insufficient clearance of oxygen radicals, but also induces the synthesis of MDA, resulting in cross-linking between molecules of the protein and in the molecule, and inducing apoptosis $(33,34)$. GSH-Px is an important peroxide-degrading enzyme that protects the structure and function of cell membranes from peroxide injury (35). In the present study, PM2.5 exposure was found to suppress the activities of SOD and GSH-Px, while enhancing MDA contents in both PIG1 cells and PIG3V cells in a concentration-dependent manner. These data suggested that the changes of oxidative stress could be responsible for PM2.5-elicited apoptosis in human melanocytes, which may be responsible for vitiligo. In addition, the activation of the Nrf2 pathway was examined, which is an important anti-oxidative stress pathway (17). The present results demonstrated that low concentrations $(0-100 \mu \mathrm{g} / \mathrm{ml})$ of PM2.5 exposure could activate the Nrf2 pathway in PIG1 cells, while this upregulation effect in PIG3V cells was not observed. This may be due to low concentration of PM2.5-induced ROS generation activating the self-protection mechanism in normal human melanocytes, while in vitiligo melanocytes the Nrf2 pathway can be some kind of dysfunction (17). The Nrf2 translocation could upregulate the expression of antioxidant genes, such as HO-1 (36). Western blot analysis demonstrated that PM2.5 exposure significantly increased the protein expression level of HO-1 in human melanocytes, and pre-incubation of ZnPP exacerbated the oxidative stress response, while hemin pre-incubation reversed the PM2.5-induced oxidative stress injury and cell death. These results suggested that HO-1 was responsible for PM2.5-induced human melanocyte injury.

Melanocyte migration and abnormal melanogenesis are both important causes of depigmentation in vitiligo $(37,38)$. Therefore, the effect of PM2.5 exposure on the migration and melanization processes of human melanocytes was examined in the present study. The present results showed that PM2.5 exposure inhibited cell migration, and attenuated the melanization process in both PIG1 and PIG3V cells. Melanocyte migration and melanogenesis are controlled by cytokines (such as SCF and bFGF) secreted by keratinocytes $(39,40)$. The exosomes secreted by keratinocytes could be involved in melanin synthesis in melanocytes $(31,41)$. The present study considered the effect of PM2.5 on cell viability, and the production of bFGF and SCF in human HaCaT keratinocytes. PM2.5 exposure inhibited the excretion of SCF and bFGF in $\mathrm{HaCaT}$ cells in a dose-dependent manner. The direct contact of keratinocytes and melanocytes was considered to be important in the melanocyte metabolism or melanin transfer.

In conclusion, PM2.5 exposure effectively induced human melanocyte apoptosis through apoptotic-related molecules and induced oxidative stress injury in human melanocytes. Furthermore, PM2.5 exposure significantly inhibited melanocyte migration, and attenuated the activation of tyrosinase and melanogenesis. Therefore, these findings suggested that PM2.5 could be a risk factor for vitiligo and may help to better understand the damaging effects of PM2.5 on the skin. 


\section{Acknowledgements}

Not applicable.

\section{Funding}

The present study was supported by CMA-L'OREAL China Skin Grant (grant no. S2016131409).

\section{Availability of data and materials}

All data generated or analyzed during this study are included in this published article.

\section{Authors' contributions}

DS performed the experiments of the current study, analyzed the data and drafted the manuscript. SZ designed the current study and supervised data analysis. JZ, LM and LW participated in study design and analyzed the data. All authors read and approved the final manuscript.

\section{Ethics approval and consent to participate}

Not applicable.

\section{Patient consent for publication}

Not applicable.

\section{Competing interests}

The authors declare that they have no competing interests.

\section{References}

1. Ezzedine K, Eleftheriadou V, Whitton M and van Geel N: Vitiligo. Lancet 386: 74-84, 2015.

2. Rodrigues M, Ezzedine K, Hamzavi I, Pandya AG, Harris JE and Vitiligo Working Group: New discoveries in the pathogenesis and classification of vitiligo. J Am Acad Dermatol 77: 1-13, 2017.

3. Ghafourian A, Ghafourian S, Sadeghifard N, Mohebi R, Shokoohini Y, Nezamoleslami S and Hamat RA: Vitiligo: Symptoms, pathogenesis and treatment. Int J Immunopathol Pharmacol 27: 485-489, 2014.

4. Huang F, Li X, Wang C, Xu Q, Wang W, Luo Y, Tao L, Gao Q, Guo J, Chen S, et al: PM2.5 spatiotemporal variations and the relationship with meteorological factors during 2013-2014 in Beijing, China. PLoS One 10: e0141642, 2015.

5. Kim JY, Lee EY, Choi I, Kim J and Cho KH: Effects of the particulate matter ${ }_{2.5}\left(\mathrm{PM}_{2.5}\right)$ on lipoprotein metabolism, uptake and degradation, and embryo toxicity. Mol Cells 38: 1096-1104, 2015

6. Wang $\mathrm{C}$, Tu Y, Yu Z and Lu R: PM2.5 and cardiovascular diseases in the elderly: An overview. Int J Environ Res Public Health 12: 8187-8197, 2015

7. Hammond D, Croghan C, Shin H, Burnett R, Bard R, Brook RD and Williams R: Cardiovascular impacts and micro-environmental exposure factors associated with continuous personal PM2.5 monitoring. J Expo Sci Environ Epidemiol 24: 337-345, 2014.

8. Li Y, Ma Z, Zheng C and Shang Y: Ambient temperature enhanced acute cardiovascular-respiratory mortality effects of PM2.5 in Beijing, China. Int J Biometeorol 59: 1761-1770, 2015.

9. Zhao J, Bo L, Gong C, Cheng P, Kan H, Xie Y and Song W: Preliminary study to explore gene-PM2.5 interactive effects on respiratory system in traffic policemen. Int J Occup Med Environ Health 28: 971-983, 2015.
10. Li Q, Liu H, Alattar M, Jiang S, Han J, Ma Y and Jiang C: The preferential accumulation of heavy metals in different tissues following frequent respiratory exposure to PM2.5 in rats. Sci Rep 5: 16936, 2015.

11. Ding A, Yang Y, Zhao Z, Hüls A, Vierkötter A, Yuan Z, Cai J, Zhang J, Gao W, Li J, et al: Indoor PM2.5 exposure affects skin aging manifestation in a Chinese population. Sci Rep 7: 15329, 2017.

12. Zhang Y, Zheng L, Tuo J, Liu Q, Zhang X, Xu Z, Liu S and Sui G: Analysis of PM2.5-induced cytotoxicity in human $\mathrm{HaCaT}$ cells based on a microfluidic system. Toxicol In Vitro 43: 1-8, 2017.

13. Deng X, Zhang F, Rui W, Long F, Wang L, Feng Z, Chen D and Ding W: PM2.5-induced oxidative stress triggers autophagy in human lung epithelial A549 cells. Toxicol In Vitro 27: 1762-1770, 2013.

14. Bekki K, Ito T, Yoshida Y, He C, Arashidani K, He M, Sun G, Zeng Y, Sone H, Kunugita N and Ichinose T: PM2.5 collected in China causes inflammatory and oxidative stress responses in macrophages through the multiple pathways. Environ Toxicol Pharmacol 45: 362-369, 2016.

15. Chu M, Sun C, Chen W, Jin G, Gong J, Zhu M, Yuan J, Dai J, Wang M, Pan Y, et al: Personal exposure to PM2.5, genetic variants and DNA damage: A multi-center population-based study in Chinese. Toxicol Lett 235: 172-178, 2015.

16. Zhou W, Yuan X, Zhang L, Su B, Tian D, Li Y, Zhao J, Wang Y and Peng S: Overexpression of HO-1 assisted PM2.5-induced apoptosis failure and autophagy-related cell necrosis. Ecotoxicol Environ Saf 145: 605-614, 2017.

17. Jian Z, Li K, Song P, Zhu G, Zhu L, Cui T, Liu B, Tang L, Wang X, Wang G, et al: Impaired activation of the Nrf2-ARE signaling pathway undermines $\mathrm{H} 2 \mathrm{O} 2$-induced oxidative stress response: A possible mechanism for melanocyte degeneration in vitiligo. J Invest Dermatol 134: 2221-2230, 2014.

18. Jian Z, Tang L, Yi X, Liu B, Zhang Q, Zhu G, Wang G, Gao T and $\mathrm{Li}$ C: Aspirin induces Nrf2-mediated transcriptional activation of haem oxygenase-1 in protection of human melanocytes from H2O2-induced oxidative stress. J Cell Mol Med 20: 1307-1318, 2016.

19. Yang L, Liu G, Lin Z, Wang Y, He H, Liu T and Kamp DW: Pro-inflammatory response and oxidative stress induced by specific components in ambient particulate matter in human bronchial epithelial cells. Environ Toxicol 31: 923-936, 2016.

20. Yu N, Zhu KJ, Ma SJ, Tang Hao and Tan XN: The total flavonoids of clerodendrum bungei suppress A549 cells proliferation, migration, and invasion by impacting Wnt $/ \beta$-catenin signaling. World J Tradit Chin Med 4: 15-20, 2017.

21. Ichikawa A, Takagi H, Suda K and Yao T: New methodological approach for the rapid and sensitive detection of melanocytes and melanocytic tumours. The DOPA-GA method. Dermatology 219: 195-201, 2009.

22. Mohamad N, Gutiérrez A, Núñez M, Cocca C, Martín G, Cricco G, Medina V, Rivera E and Bergoc R: Mitochondrial apoptotic pathways. Biocell 29: 149-161, 2005.

23. Pisoschi AM and Pop A: The role of antioxidants in the chemistry of oxidative stress: A review. Eur J Med Chem 97: 55-74, 2015.

24. Lee C: Collaborative power of $\mathrm{Nrf} 2$ and PPAR $\gamma$ activators against metabolic and drug-induced oxidative injury. Oxid Med Cell Longev 2017: 1378175, 2017.

25. Colucci R, Dragoni F and Moretti S: Oxidative stress and immune system in vitiligo and thyroid diseases. Oxid Med Cell Longev 2015: 631927, 2015.

26. Repnik U, Česen MH and Turk B: The endolysosomal system in cell death and survival. Cold Spring Harb Perspect Biol 5: a008755, 2013.

27. Estaquier J, Vallette F, Vayssiere JL and Mignotte B: The mitochondrial pathways of apoptosis. Adv Exp Med Biol 942: 157-183, 2012.

28. Shalini S, Dorstyn L, Dawar S and Kumar S: Old, new and emerging functions of caspases. Cell Death Differ 22: 526-539, 2015.

29. Slimen IB, Najar T, Ghram A, Dabbebi H, Ben Mrad M and Abdrabbah M: Reactive oxygen species, heat stress and oxidative-induced mitochondrial damage. A review. Int $\mathrm{J}$ Hyperthermia 30: 513-523, 2014.

30. Kupsco A and Schlenk D: Oxidative stress, unfolded protein response and apoptosis in developmental toxicity. Int Rev Cell Mol Biol 317: 1-66, 2015.

31. Shi Q, Zhang W, Guo S, Jian Z, Li S, Li K, Ge R, Dai W, Wang G, Gao T and Li C: Oxidative stress-induced overexpression of miR-25: the mechanism underlying the degeneration of melanocytes in vitiligo. Cell Death Differ 23: 496-508, 2016. 
32. Hu R, Xie XY, Xu SK, Wang YN, Jiang M, Wen LR, Lai W and Guan L: PM2.5 exposure elicits oxidative stress responses and mitochondrial apoptosis pathway activation in $\mathrm{HaCaT}$ keratinocytes. Chin Med J (Engl) 130: 2205-2214, 2017.

33. Shi MH, Wu Y, Li L, Cai YF, Liu M, Gao XH and Chen HD: Meta-analysis of the association between vitiligo and the level of superoxide dismutase or malondialdehyde. Clin Exp Dermatol 42: 21-29, 2017.

34. Li QL, Wu YH, Niu M, Lu XJ, Huang YH and He DH: Protective effects of tacalcitol against oxidative damage in human epidermal melanocytes. Int J Dermatol 56: 232-238, 2017.

35. Karsli N, Akcali C, Ozgoztasi O, Kirtak N and Inaloz S: Role of oxidative stress in the pathogenesis of vitiligo with special emphasis on the antioxidant action of narrowband ultraviolet $B$ phototherapy. J Int Med Res 42: 799-805, 2014.

36. Bao L, Li J,Zha D, Zhang L, Gao P, Yao T and Wu X: Chlorogenic acid prevents diabetic nephropathy by inhibiting oxidative stress and inflammation through modulation of the Nrf2/HO-1 and NF-kB pathways. Int Immunopharmacol 54: 245-253, 2018.
37. Goldstein NB, Koster MI, Hoaglin LG, Spoelstra NS, Kechris KJ, Robinson SE, Robinson WA, Roop DR, Norris DA and Birlea SA: Narrow band ultraviolet B treatment for human vitiligo is associated with proliferation, migration, and differentiation of melanocyte precursors. J Invest Dermatol 135: 2068-2076, 2015.

38. Yang L, Wei Y, Sun Y, Shi W, Yang J, Zhu L and Li M: Interferon-gamma inhibits melanogenesis and induces apoptosis in melanocytes: A pivotal role of CD8+ cytotoxic T lymphocytes in vitiligo. Acta Derm Venereol 95: 664-670, 2015.

39. Kim HJ, Bae IH, Son ED, Park J, Cha N, Na HW, Jung C, Go YS Kim DY, Lee TR and Shin DW: Transcriptome analysis of airborne PM2.5-induced detrimental effects on human keratinocytes. Toxicol Lett 273: 26-35, 2017.

40. Videira IF, Moura DF and Magina S: Mechanisms regulating melanogenesis. An Bras Dermatol 88: 76-83, 2013.

41. Lo Cicero A, Delevoye C, Gilles-Marsens F, Loew D, Dingli F, Guéré C, André N, Vié K, van Niel G and Raposo G: Exosomes released by keratinocytes modulate melanocyte pigmentation. Nat Commun 6: 7506, 2015.

This work is licensed under a Creative Commons Attribution-NonCommercial-NoDerivatives 4.0 International (CC BY-NC-ND 4.0) License. 